\title{
Proposed Business Strategy for Small Medium Enterprises (SMEs) (Case Study: Rimbang SMEs of Clothing Industry)
}

\author{
Arifa Amalina Izni; Harimukti Wandebori
}

\begin{abstract}
Rimbang is one of Small Medium Enterprises (SMEs) of Clothing Industry that provides kids professional uniforms in Bandung, Indonesia. At present, as the growth of SMEs continues to increase and with the presence of marketplace platforms become one of the causes of the decline in product sales over the last three years, namely in the years 2017, 2018 and 2019.

This research was conducted to develop the most suitable strategy based on existing internal and external factors. The results of internal factors analysis demonstrate the strength of reputation and good relationship and weakness in the form of a product type that is seasonal and easily emulated. The results of external factors analysis show the opportunity of online sales and future integration and threats in the form of potential newcomers and higher competencies. Analysis results are used to formulate strategies using SWOT Analysis, TOWS Matrix and Porter's Generic Strategy.

The proposed strategy is the Cost Leadership Strategy and Forward Integration as a strategy used to improve and develop existing business strategies and marketing strategies. These strategies are done by developing limited resources, implementing effective value chain activities and conducting product marketing directly to end consumers through online and offline sales.
\end{abstract}

Index Terms - Business Strategy, Marketing Strategy, Small Medium Enterprises (SMEs).

\section{INTRODUCTION}

Based on the road map of Making Indonesia 4.0, the development of textile and clothing industry sectors become one of five prior manufacturing sectors in the industrial era 4.0. The growth of the textile and clothing industry is $8.73 \%$ higher in 2019 and increasing the rivalry competition among the industry. Making Indonesia 4.0 contains one of the national initiatives to accelerate the development of manufacturing industry in Indonesia, the initiative is related to Small and Medium Enterprises (SMEs) empowerment [1].

According Business Profile of Micro, Small, and Medium Enterprises (SMEs) from Bank Indonesia, SMEs are classified into four different based on assets and turnover profiles [2]:

- Microbusiness with assets worth at most IDR 50 million and the turnover result at most IDR 300 million;

- Small business with assets worth > IDR 50 million 500 million and the turnover result > IDR 300 million - IDR 2,5 billion;
- Medium business with assets worth > IDR 500 million -10 billion and the turnover result > IDR 2,5 billion - IDR 50 billion;

- $\quad$ Large business with assets worth > IDR 10 billion 500 million and the turnover result > IDR 500 billion.

Small and medium-sized industries in its development have seven fundamental constraints consisting limitation of capital, limitation of raw materials, limitation of production capacity, limitation of promotion and marketing, limitation of technology, limitation of human resources, as well as the absence of a network of partnerships affecting the limitations of small industrial products challenging to compete in the global market [3]

Rimbang is a company engaged in convection industry that produces kids professional uniforms with a small scope of production and distribution ability located in Bandung, Indonesia. Because of kids professional uniforms categorized as a seasonal products, so that he sales and product demand will experience an increase in a particular season.

The challenges is due to the development of technology and information with the increasing of e-commerce platforms. E-commerce platforms are one of the methods of online spending that affects consumer behavior in conducting transactions. Another challenges is due to the increasing of convection industry growth leads to increasing an intense competition. The challenges should be quickly adapted to continuously utilize a resource and increase a functional capability as core competence to get a competitive advantage.

The inability of the company to face current challenges leads to a decrease in the number of product sales, especially during the last three years from 2017 to 2019 causing a highlevel of inventory. The company should be able to continuously improve the business process using an effective business strategy in generating more profit and improve company sustainability. The ability of strategic implementation can be made from the strategic management process, the approach that companies use in an industry to have core competencies to achieve competitive advantage.

\section{RESEARCH METHODOLOGY}

The research is conducted by using a qualitative research approach. Qualitative research is a study conducted based on the merging techniques of data collection and the inductive analysis of data. Qualitative research results in descriptive data based on direct observation of actual problems. The conceptual framework used for this research shown in Fig.1 :

Published on August 21, 2020.

Arifa Amalina Izni, Bandung Institute of Technology, Indonesia.

(corresponding e-mail: arifa.amalina@sbm-itb.ac.id)

Harimukti Wandebori, Institut Teknologi Bandung, Indonesia.

(e-mail: harimukti@sbm-itb.ac.id) 


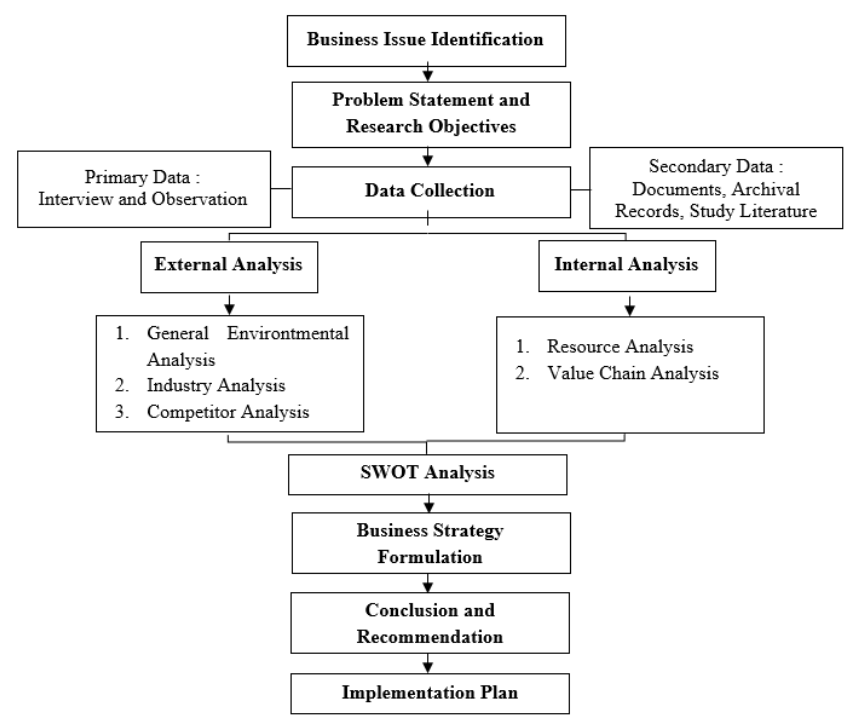

Fig. 1. Conceptual Framework.

\section{FINDINGS AND ARGUMENT}

\section{A. External Factors Analysis}

External analysis is done by analyzing the external environment consisting of general environment analysis using PEST analysis, industry analysis using Porter's Five Forces, and competitor analysis. General environment analysis is conducted using PEST analysis that consists of analyzing political, economic, social, and technology factors [4]. In political factors, some support services offered by the government to develop the SMEs sector by lowering finance barriers, raising SMEs awareness, and strengthening networks. the government also implements the required regulations, including the legality of business licensing specified in the Peraturan Pemerintah (PP) Number 98/ 2014, taxation regulation specified in Peraturan Pemerintah (PP) Number 23/2018. Law No. 20/2008 also implemented to empower SMEs thoroughly, optimally and sustainably. In economic factors, GDP annual growth rate during the period of 2017 - 2020 decreased with a stable GDP value above the average of $5 \%$ and the inflation rate in Indonesia from March 2019 to March 2020 increased with the inflation rate in March 2019 by $2.48 \%$ and increased to $2.96 \%$ in March 2020. In sociocultural factors, until the year 2018 demographics in Indonesia showed that the population of Indonesia reached 265 million people consisting of 133.17 million men and 131.88 million women, based on the highest population age group in children (0-14 years) with a population of 70.49 million, this age group is an industrial target market, especially groups of elementary school children and kindergartens. In technological factors, the development of technology that is moving rapidly has an impact on increasing the number of Internet users in a variety of general public in Indonesia. The latest technology presence, such as IoT and Big Data, also increases the e-commerce industry that provides many positive and negative impacts on business people, consumers, and society.

Industry analysis is conducted using Porter's five forces method. Porter's five forces analysis consists of bargaining power of buyers, bargaining power of suppliers, a threat of new entrants, a threat of substitute products or services, and rivalry among existing competitors [5]. The results of industry analysis summarized in following Table.1.

TABLE 1. THE Summary OF PORTER's FIVE ForCES ANALySIS

\begin{tabular}{|c|c|c|}
\hline & Factors & Implication \\
\hline $\begin{array}{l}\text { Bargaining Power } \\
\text { of Buyers }\end{array}$ & $\begin{array}{l}\text { - Product differentiation (low) } \\
\text { - Switching cost (low) } \\
\text { - Backward integration (medium) } \\
\text { - Profitability impacts (high) }\end{array}$ & $\begin{array}{c}\text { High Bargaining Power of } \\
\text { Buyers }\end{array}$ \\
\hline $\begin{array}{l}\text { Bargaining power } \\
\text { of suppliers }\end{array}$ & $\begin{array}{l}\text { - Switching cost (low) } \\
\text { - Ability to switch (high) } \\
\text { - Suppliers option (high) }\end{array}$ & $\begin{array}{l}\text { Low Bargaining Power of } \\
\text { Suppliers }\end{array}$ \\
\hline $\begin{array}{l}\text { The threat of new } \\
\text { entrants }\end{array}$ & $\begin{array}{l}\text { - Capital requirement (medium) } \\
\text { - Product differentiation (low) } \\
\text { - Technology requirement (low) } \\
\text { - Skills requirement (low) } \\
\end{array}$ & $\begin{array}{l}\text { Medium The threat of new } \\
\text { entrants }\end{array}$ \\
\hline $\begin{array}{l}\text { The threat of } \\
\text { substitute products }\end{array}$ & $\begin{array}{l}\text { - Switching cost (low) } \\
\text { - Access to substitute products (medium) }\end{array}$ & $\begin{array}{l}\text { Medium The threat of } \\
\text { substitute products }\end{array}$ \\
\hline $\begin{array}{l}\text { Rivalry among } \\
\text { existing } \\
\text { competitors }\end{array}$ & $\begin{array}{l}\text { - Competitive intensity (medium) } \\
\text { - Industry growth (small) } \\
\text { - Exit barriers (medium) } \\
\text { - Number of competitors (medium) } \\
\text { - Product differentiation (low) } \\
\end{array}$ & $\begin{array}{l}\text { Medium Rivalry among } \\
\text { existing competitors }\end{array}$ \\
\hline
\end{tabular}

In competitor analysis, currently, Rimbang has direct competitors who are in the same strategic group with similar target segments, Commando and Kijang are two competitors who are currently competing within the same strategic group, the results of competitor analysis shown that competitor doing better marketing techniques by not only offline but also online market, being a reasonably aggressive competitor.

\section{B. Internal Factors Analysis}

Internal analysis is conducted to determine two elements, strengths and weaknesses of the company. The framework consists of resources analysis and value chain analysis used to achieve a competitive advantage based on the capabilities and core competence of the company [6].

Resources analysis consists of analyzing both tangible and intangible resources [6]. For tangible resources, in terms of financial resources, company has not received funding assistance from third parties to fund. The initial capital of the company comes from personal funds, and for the operational funds used are derived from the sales revenue. In terms of organizational resources, planning and control activities through direct and unwritten coordination, it becomes a weakness of organizational resources available because it can cause miscommunication and misunderstanding. Facilities, tools and machines as a physical resource can be used optimally to support operational activities. In technological resources, the company has not updated recent technology to create a unique product, patents or copyrights. For intangible resources, lack of human resources in the quality control and packaging team become a problems that cause the process of quality control become longer and potentially cause the process of packaging and delivery of products become inefficient. The company has not has not conducted optimally or periodically product innovations yet, but the company has a good reputation amon the customers, suppliers and has a good relation with customers and suppliers that benefit the company.

Value chain aims to create a higher value for customers than the costs used to create that value. The value chain analysis consists of primary activities that create direct value for customer and support activities that support primary 
activities, and it is carried out continuously to improve operational efficiency and to gain a higher value [6]. Primary activities consists of inbound logistics, operations, outbound logistics, marketing-sales and services. For inbound logistics, operations to outbound logistics, those activities have not been performed optimally and inefficient, marketing and sales activities performed using B2B strategy between two business, but services activities become the strength that has satisfied customers and help maintained customer loyalty. For support activities consist of firm infrastructure, procurement, human resource management, and technology development. In terms of firm infrastructure lack of financial management and Rimbang have not been optimally performed a production planning that causes to uncontrolled production process that leads to high inventory, excess inputs or outputs include causing a higher costs and risks. Also, procurement activities performed without a fixed procurement schedule, and without taking any contracts with certain suppliers. In terms of human resources management, here are some human resources who can not be able to achive weekly production goals with a low performance becomes a threat that affects the operational costs but lowers productivity of production activities. Last, Rimbang chose to perform high maintenance of current technology.

\section{SWOT Analysis}

SWOT analysis is a framework used to evaluate the strength and weaknesses of the company's internal, as well as an evaluation of opportunities and threats in the organizational environment or from external companies. SWOT analysis aims to improve the organizational knowledge in formulating appropriate strategies in the organizational environment. [7] The SWOT analysis can be seen in the following table :

TABLE 2: SWOT ANALYSIS

\begin{tabular}{|c|c|}
\hline Strength (S) & Weakness (W) \\
\hline $\begin{array}{l}\text { 1. Strategic location give an } \\
\text { advantage in support daily } \\
\text { operational actitivites } \\
\text { 2. Good reputation among the } \\
\text { customers increase customer } \\
\text { loyalty } \\
\text { 3. Good relation with supplier and } \\
\text { customers } \\
\text { 4. After sales services increase } \\
\text { customer satisfaction and customer } \\
\text { loyalty } \\
\text { 5. Selective quality management } \\
\text { 6. Continuous improvemet in product } \\
\text { quality }\end{array}$ & $\begin{array}{l}\text { 1. Seasonal products } \\
\text { 2. Products are easy to imitate } \\
\text { 3. Limited financial resources and } \\
\text { financial management } \\
\text { 4. Lack of human resources } \\
\text { management } \\
\text { 5. Nonoptimal packing process } \\
\text { 6. Low product differentiation } \\
\text { 7. High inventory that increases } \\
\text { costs } \\
\text { 8. Lack of marketing activities }\end{array}$ \\
\hline Opportunity $(\mathbf{O})$ & Threat (T) \\
\hline $\begin{array}{l}\text { 1. Goverment supports programs for } \\
\text { development of SMEs sectors } \\
\text { 2. Regulations implemented to } \\
\text { empower SMEs thoroughly } \\
\text { 3. Indonesia culture in celebrate some } \\
\text { momentum } \\
\text { 4. Increase in technology such as } \\
\text { marketplace platforms } \\
\text { 5. Digital marketing and online sales } \\
\text { activities } \\
\text { 6. Emerging of internet user in } \\
\text { Indonesia } \\
\text { 7. Forward integration to reach end } \\
\text { customers }\end{array}$ & $\begin{array}{l}\text { 1. Emeging of potential newcomers } \\
\text { 2. High competition markets within } \\
\text { the industry } \\
\text { 3. High bargaining power of buyers } \\
\text { 4. Buyers potentially do a backward } \\
\text { integration } \\
\text { 5. Competitor pressure } \\
\text { 6. Decrease in GDP and increase in } \\
\text { inflation rate of economic sectors }\end{array}$ \\
\hline
\end{tabular}

\section{Root Cause Analysis}

Root cause analysis consists of three main factors consist of effects, problems, and causes. Root cause framework used to find the root causes of primary business issue. The results of root cause analysis shown in following figure

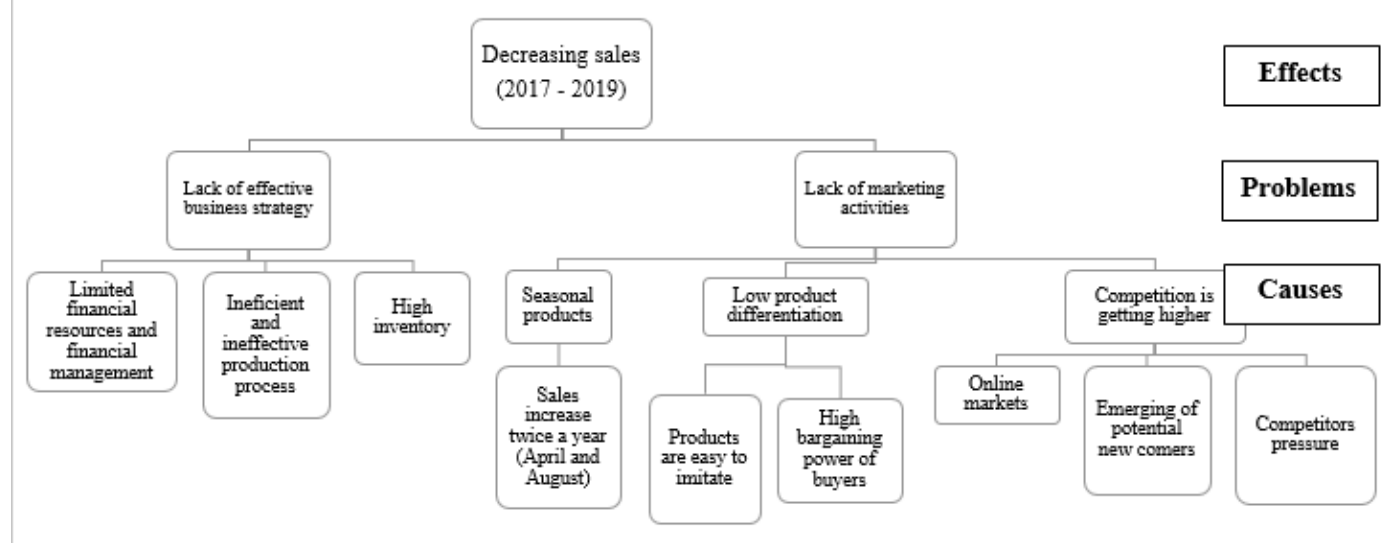

Fig. 2. Root Cause Analysis.

\section{IV.RESULTS AND SOLUTIONS}

\section{A. Proposed Business Strategy}

Based on the results of internal and external factors analysis, Rimbang, as a convection industry that produces kids professional uniforms, has limited resources with the value chain activities that have not been optimally used. Those kinds of weaknesses are challenging to deal with fast market growth and highly competitive markets and to experience obstacles in getting maximum profit. Based on the analysis conducted against the strengths and weaknesses factors of the company's internal as well as the threat and opportunity factor of the organizational environment as an external company by using SWOT analysis, the formulation of business strategy continued by using the TOWS matrix.

\section{Michael Porter's Generic Strategies}

Based on internal factors analysis (resources analysis and value chain analysis), and external factors analysis (general environmental analysis, industry analysis, and competitor analysis) conducted, $\neg$ cost leadership $\neg$ type $1-$ low cost strategy must be pursued as the primary strategy to produce products or service at the lowest price available of the market 
to a wide range of customers who are price sensitive and do not care about differences among brands with similar products. This strategy effectively used under the conditions when the products of competitor are essentially identical, customers use the products in the same ways, and customers incur low switching costs. This strategy conducted to gain market share and sales by performing value chain activities to be more efficient and effective and by using well optimized resources [8].

Vertical integration strategies conducted to support primary strategy of cost leadership strategy that used to gain control over distributors and to gain low cost leadership benefits. Currently, products are distributed through intermediaries party such uniform store as retailer in several cities in Java Island, Indonesia. Forward integration strategy conducted by using Internet technology optimally to market the products through e-commerce platforms or other online marketplace platforms. It aims to lower the costs derived from the distribution process so that the base price of the product becomes lower [8]

\section{TOWS Matrix}

Matrix TOWS is a framework used as an advanced stage analysis of the SWOT analysis that has been done by developing four types of strategy, namely SO strategy, WO strategy, ST strategy, and WT strategy. This framework is used to formulate a business strategy based on existing internal and external factors. TOWS matrix shown in following figure below:

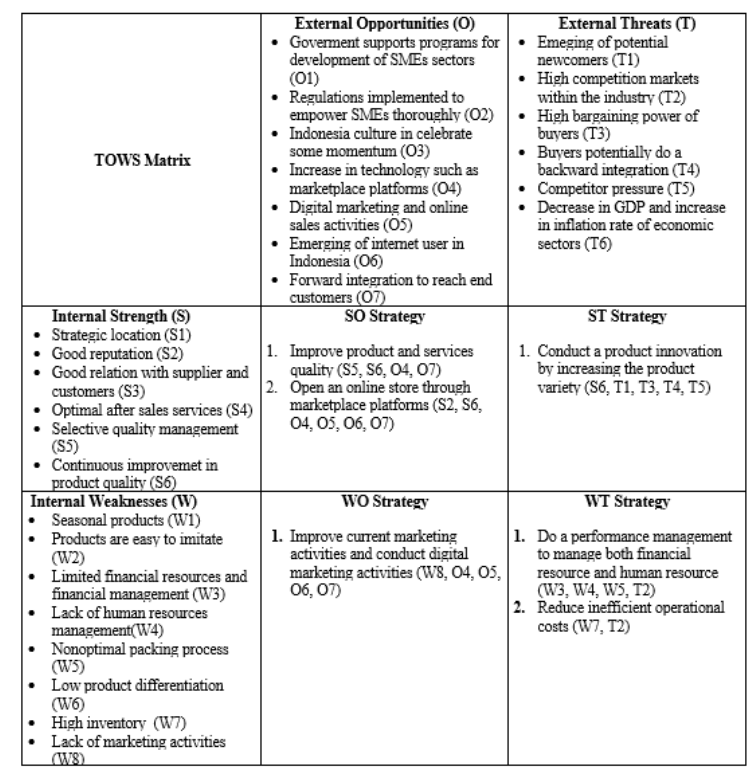

Fig. 3. TOWS matrix.

Based on the results of the TOWS analysis for generating strategic options, the strategy can be developed by improving current products and service quality and expanding marketing activities through online platforms as the SO strategies to take the best advantage of the opportunities, and improving value chain and resources as the WT strategies to protect from loss and minimize the impact of weaknesses against threats. This strategy is the most suitable strategy related to cost leadership type 1 -low cost strategy as the primary strategy to produce products or service at the lowest price available of the market to a wide range of customers who are price sensitive and do not care about differences among brands with similar products. Vertical integration strategies conducted to support primary strategy of cost leadership strategy that used to gain control over distributors and to gain low cost leadership benefits.

\section{Proposed Resources Analysis}

Rimbang is a household convection industry in the field of Small Medium Enterprises (SMEs), the company has limited resources, both tangible and intangible resources, because of limited capital owned by the company. Limited capital leads to the inability of the company to have an optimal bundling resource and limit the capabilities of the company to create core competencies and achieve a competitive advantage.

With the increase of financial resources, it can further improve the company's ability to increase the organization resources in planning, controlling, and coordinating that used to increase the efficiency and effectiveness of value chain activities, and followed by increased technological resources. In addition to improving tangible resources, it can also help to enhance the knowledge and skills of human resources owned by the company through some training and to increase company innovation and reputation.

\section{Proposed of Developing Value Chain Activities}

The development of value chain activities helps the company to understand which operational activities that create value and that do not; the value that is greater than the costs incurred helps the company to earn above-average returns. The development of value chain activities is conducted by measuring and evaluating the effectiveness of current primary activities and support activities to create value, and the development is conducted to add a higher value.

In primary activities that consists of inbound logistics, operations, outbound logistics, sales-marketing, and service the development should be performed by establishing a clear Standard Operational Procedure (SOP) to prevent problems in carrying out inventory control, maintaining a good relationship with suppliers will benefit the company that can strive for cost savings over the long term, reduces delays and quality issues that increase production efficiency, doing a periodically maintenance for the equipments instead of replacing the broken tool into a new one to lower the costs; developing product innovation, gathering and evaluating ideas for new products and product improvements to serve the same customers for a long period of time follows with the latest mode developments; maintaining a good communication and relationship to customers should be conducted to keep customer loyalty and satisfaction to add more value within service activities

In support activities, Rimbang required to do an optimal financial statements that used to evaluate the position and change of financial position and the company's financial management performance, applying the procurement schedulling, utilizing and updating new technology of the usage of social media, and the use of online platforms to get a competitive advantage, selecting a capable human 
resources; tracking their performance and performing a rewards system to get a better human resources management

\section{B. Proposed Marketing Strategy}

marketing strategy is the marketing logic that consists of a broad plan for achieving its marketing objectives, creating customer value, and achieving a profitable relationship (Kotler). Proposed marketing strategy consists of Segmenting, Targetting and Positioning (STP) analysis, marketing mix, proposed value proposition, Points-ofDifference (POD) and Points-of-Parity (POP) [9].

\section{Segmenting, Targetting, and Positioning (STP)}

With the ability to be able to compete in the competitive market today, companies should be able to provide higher value to win customers from competitors. The company should be able to divide the total market by the best market segment and set a strategy to gain profit from the Choosen segment because there are a lot of different kinds of consumers who have different kinds of needs and wants.

Market segmentation consists of geographic segment in the region of Banten province, West Java province and Central Java province. Demographic segment based on a gender variable consisting of gender male and female, as well as an age variable consisting of ages 2-10 years (children); 11-20 (adolescents), 26-25 years (early adulthood); 36-45 years old (adult), > 55 years (senior). psychographic segment consists of lower class with relatively low income and low educated, middle class with higher education and high income classes, and upper class marked by the magnitude of wealth, highincome, high-educated and family stability. Behavioral segment consist of consumers behaviour that has product purchase criteria based on design, price, quality and product range.

Based on the type of product offered by Rimbang, the target market is determined based on the differentiated marketing strategy in which the company targets several types of market segments and aims to increase higher sales with a stronger position in the market segment. The Market targetting applied consist of Group of buyers from the region of Banten province, West Java province and Central Java province, male and female gender from the age of 2-10 (children); 11-20 (adolescents), 26-25 years (early adulthood); 36-45 years (Akhr adult), > 55 years (senior), in the middle of social class with educational classes and high income, have the criteria of purchasing products kids professional uniforms with a price range of IDR $75.000-$ 150.000; Quality is assured and with a varied product range profession.

Positioning is based on companies that position itself as one of the companies that have the credibility in producing kids professional uniforms quality products from the city of Bandung and to date already serve the sale of products in several major cities in the island of Java.

\section{Marketing Mix}

Marketing mix used to estimate causal relationships and measure how marketing activtiy affects outcomes. Marketing mix consists of product, price, promotion, place. products consist of professional uniform of several profession groups for gender male and female with a range 2-10 year (children).
Product variety consists of products for the category of profession groups consist of military group for Army profession, navy and Air Force, pilot group and stewardess, general Practicioner Group for profession doctor and nurse, and profession Police group. Products are available in sizes of the number one to twelve meaning tailored to the target user's age of product. Price range from IDR 100,000 to IDR 175,000. Promotion can be developed using business-tocustomer (B2C) sales system through online marketing using media online through social media platforms or using ecommerce platforms. In addition promotion activities can be increased based on customer satisfaction to the created word of mouth communication. Proposed marketing strategy towards place attributes business-to-customers activities where the products are directly distributed to customers without intermediaries party.

\section{Proposed Value Proposition}

Value proposition analysis can be done using the value proposition canvas explaining the specifications of the value in the business model become more structured and detailed. Value proposition map consist of two parts, the first one of namely product and service, gain generator and pain reliever and the second of customer point of view namely customer jobs, customer pain and customer gain.

In customers perspective, customer jobs from customers Rimbang is the need for a quality kids professional uniforms with an affordable price to fulfill the desire to use kids professional uniforms in the fashion event carnaval on a particular celebration day or desire to use kids professional uniforms in a specific purpose. Customer pains from the customer Rimbang comes from a change of realistic price factor. Good quality product with affordable price to be the main customer gain.

In product perspective, the main products and services provided by the company to customers. Product trade of kids professional uniforms quality with affordable price. Affordable price product offerings with the same usability value is the main solution to overcome customer pains. Gains Creator can be created by creating a satisfying kids professional uniform product, a more comfortable quality of materials to be used, clothing models that are easier to use with complete attributes and quality maintained to more value for the product.

\section{Points of Difference (PODs)}

Points of Difference (PODs) are attributes or benefits that distinguish from competitors to brands, positive evaluation and trust, PODs creates strong, profitable and unique relationships as a challenge and an important factor for competitive brand position. A brand association can truly function as a point-of-difference determined by three kinds of criteria, desirability; deliverability; and differentiability [10]. Points of Difference (POD) of Rimbang products consist of :

1) Clothing Model always updated.

2) Providing kids professional uniform for around 20s years.

3) Clothing size set based on customers age target. 


\section{Points of Parity (POP)}

Points-of-Parity (POPs) are attributes and benefits association that are not necessarily unique and commonly shared with other brands. These types of association consist of two basic forms namely category POPs when attributtes and benefits are essential, necessary but not sufficient enough for brand choice, while competitive POPs are association to vercome perceived weakness [10]. Points of Parity (POP) of Rimbang products consist of :

1) Providing professional uniform for kids.

2) Distribution channels through intermediaries parties such as uniform store.

3) The production system used is the convection production system in which the production process is done in bulk.

\section{CONCLUSION}

Based on the results of such internal and external factor analysis, the author propose a business strategy to overcome the problem issues corresponds to the internal and external conditions available. In this chapter, the author will explain the conclusion, resource requirement and implementation plan to propose a business strategy for Rimbang Company.

The conclusion is about the external and internal condition of Rimbang that causes problems, the proposed strategy to overcome the problems and the implementation plan to overcome the problem issues

1) Rimbang experienced a decline in sales from 2017 2019 , this is due to the increasingly intense competition, especially with the technological advancement in the form of online marketplace platforms. Companies that can not perform production plans optimally comparable to the declining marketing causing over production and causing losses due to the buildup of raw material goods or finished goods in inventory

2) Based on the available internal and external conditions, the most suitable strategy is the cost leadership low cost strategy as a long-term strategy through the efficiency of value chain activities process to reduce cost, optimize resources usage and implement forward integration strategy by marketing and direct sales to end customers by utilizing online marketplace platforms and digital marketing activities.

\section{REFERENCES}

[1] Kementrian Perindustrian Republik Indonesia. Making Indonesia 4.0.

[2] Bank Indonesia. 2015. Profil Bisnis Usaha, Kecil dan Menengah (UMKM)

[3] Malikhatin, (2016). Study Perbandingan Usaha Konveksi Elkhana Collection dan D\&Y Collection Menggunakan Analisis SWOT Untuk Pengembangan Usaha. Kearsipan Jurusan Syariah dan Ekonomi Islam, STAIN Kudus.

[4] Wandebori, H. (2019). Manajemen Strategi dalam Perspektif Indonesia. Bandung: ITB Press.

[5] Porter, Michael. E. (1998) The Five Competitive Forces That Shape Strategy. Harvard Business Review January 2008.

[6] Hitt, Michael A., Ireland, R. Duane and Hoskisson, Robert E., (2001) Strategic Manajement: Competitiveness and Globalization, Edisi Bahasa Indonesia, Jakarta, Salemba Empat.

[7] Sammut-Bonnici, Tanya \& Galea, David. (2015). SWOT Analysis. Retrived from 10.1002/9781118785317.weom120103.
[8] David, F. (2011). Strategic Management, Concept, and Cases 13th edition. Upper Sadle River, NJ: Pearson Prentice Hall.

[9] Kotler, Armstrong. (2016). Principles of Marketing 16/e. United States: Pearson Education.

[10] Kotler, Keller. (2012). Marketing Management 14/e. New Jearsey: Prentice Hall.

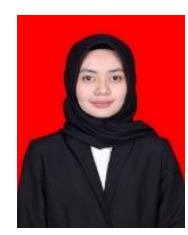

Arifa Amalina Izni was born in Bandung, November 16,1995 and she was graduated from Jenderal Achmad Yani University, Cimahi-Indonesia in 2017 majoring Pharmacy Studies. She currently pursuing master degree majoring Business and Administration in School Business and Management at Institut Teknologi Bandung, Indonesia.

Her working experience in an internship program at PT. Kimia Farma unit Research and Development Bandung and at PT. Telkom Indonesia unit Division Digital Service (Telkom DDS) Bandung

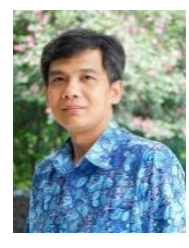

Harimukti Wandebori earned his undergraduate in majoring in electrical engineering at Institut Teknolog Bandung, later $\mathrm{He}$ continued his postgraduate in Maastricht School of Management to get Master in Business Administration, and Doctor in management at University of Twente, Netherlands.

$\mathrm{He}$ is an assistant professor of Business Strategy and Marketing Interest Group who has a research interest in strategic management at School of Business and Management, Institut Teknologi Bandung (SBM-ITB) 